TAO, Vol. 13, No. 3, 339-354, September 2002

\title{
Formation of the Taiwan Island as a Solitary Wave along the Eurasian Continental Plate Margin: Magnetic and Seismological Evidence
}

\author{
Chengsung Wang ${ }^{1,2,{ }^{*}}$, Chih-Ping Huang ${ }^{1}$, Lei-Yui Ke ${ }^{1}$, Wen-Ju Chien ${ }^{1}$, Su-Kun Hsu ${ }^{3}$, Chun-Tien Shyu ${ }^{4}$, \\ Win-Bin Cheng ${ }^{5}$, Chao-Shing Lee ${ }^{1}$, and Louis S. Teng ${ }^{6}$
}

(Manuscript received 13 May 2002, in final form 9 August 2002)

\begin{abstract}
The Philippine Sea plate moves northwestward, with respect to the Eurasian plate, and produces the Ryukyu subduction system (including the Ryukyu trench, the Ryukyu arc and the Okinawa trough) and the Manila subduction system (including the Manila trench and the Luzon arc) with opposite polarity of subduction on the plate boundary along the RyukyuTaiwan-Luzon region. The transition zone between these two subduction systems is the Taiwan island, with vigorous mountain building in the south and gravitational collapsing in the north. Thus, the Taiwan island propagates southwestward as a solitary wave along the Eurasian continental plate margin, with a speed of about $7 \mathrm{~cm} / \mathrm{y}$. In this paper, we describe the occurrence environment for this phenomenon, with morphological, magnetic and seismological evidence.

The shifting oblique lithospheric convergence of the Philippine Sea plate with the Eurasian continental plate margin causes the transient solitary wave of the Taiwan island. The convergence has squeezed the tectonic zones near the plate boundary tightly and uplifted the transition zone that is the Taiwan island. When the convergence site migrates southwestward along the continental plate margin, the squeezed parts of these tectonic zones are released again and spread, by the following tensional stress due to the northward subduction of the Philippine Sea plate. Therefore, the area of the Taiwan island does not necessarily increase substantially with geological time. In order to better understand the lithospheric interaction in the Taiwan area, we also proposed a lithospheric convergence model in this paper.
\end{abstract}

\footnotetext{
${ }^{1}$ Institute of Applied Geophysics, National Taiwan Ocean University, Keelung 202, Taiwan

${ }^{2}$ Division of general Education, Chin Min college, Toufen, Maoli County 351, Taiwan

${ }^{3}$ Institute of Geophysics, National Central University, Chungli, Taoyuan County 320, Taiwan

${ }^{4}$ Institute of Oceanography, National Taiwan University, Taipei 106, Taiwan

${ }^{5}$ Library, Jin-Wen Institute of Technology, Taipei County 231, Taiwan

${ }^{6}$ Department of Geology, National Taiwan University, Taipei 106, Taiwan

* Corresponding author address: Prof. Chengsung Wang, Institute of Applied Geophysics, National Taiwan Ocean University, Keelung 20224, Taiwan; E-mail: wangcs@mail.ntou.edu.tw
} 
(Key words: Taiwan island, Oblique lithospheric convergence, Solitary wave, Mountain building and collapsing, Magnetic and seismological evidence)

\section{INTRODUCTION}

The interaction between the northwestward-moving Philippine Sea plate and the Eurasian plate is intense and complicated near Taiwan (Fig. 1), as indicated by the frequent earthquakes (Figs. 2 and 3). In the north, the Philippine Sea plate subducts beneath the Eurasian plate to form the Ryukyu subduction system, including the Ryukyu trench, the Ryukyu arc and the

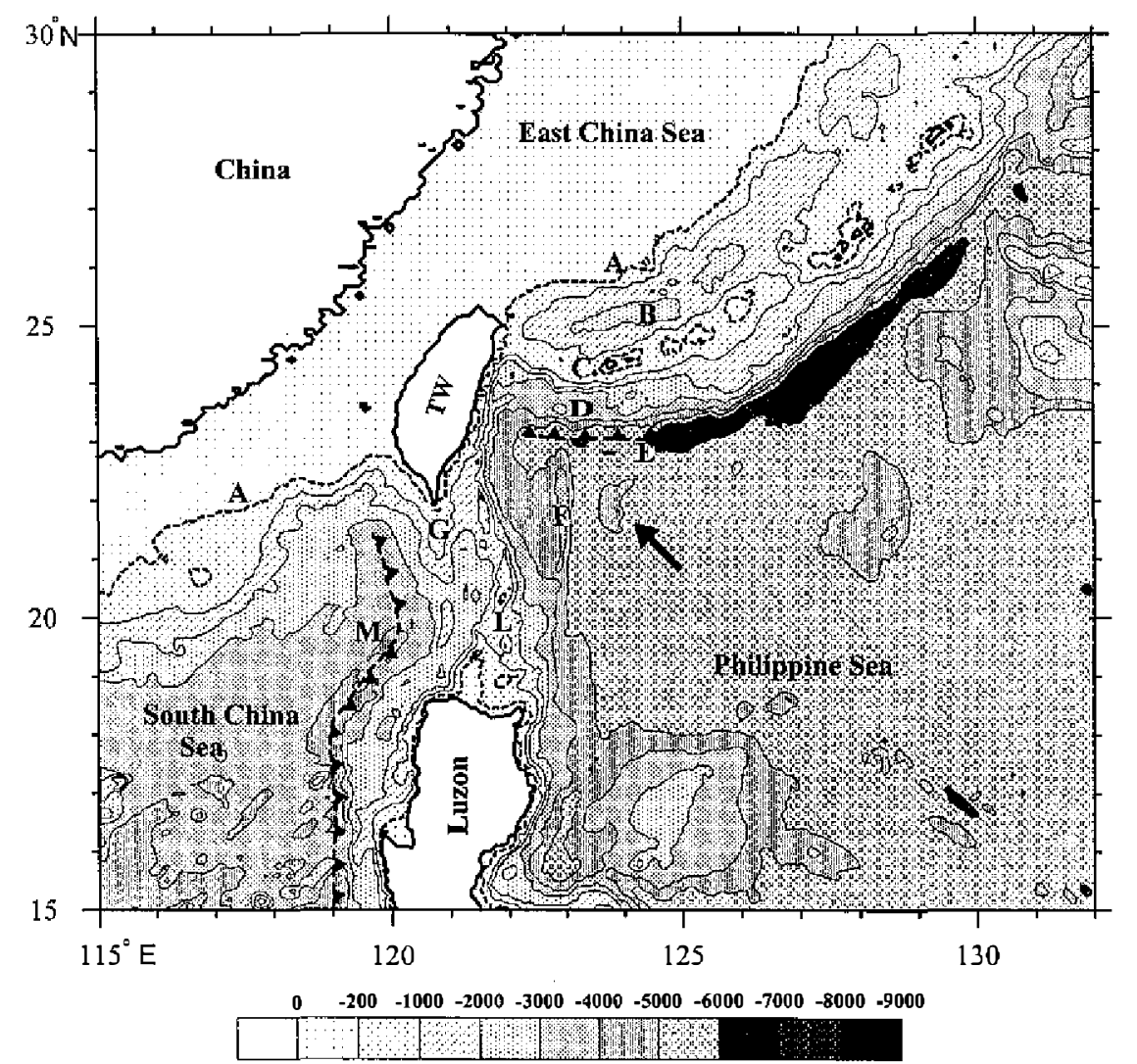

Fig. I. Bathymetric and tectonic units in the Ryukyu-Taiwan-Luzon region. A: Chinese continental shelf edge; B: Okinawa trough; C: Ryukyu island arc; D: Yaeyama ridge, the forearc ridge; E: Ryukyu trench; F: Gagua ridge; G: Hengchun ridge, the accretionary prism; L: Luzon arc; M: Manila trench; TW: the Taiwan island, the transition zone between the Ryukyu subduction system (A-E) and the Manila subduction system (G, L, M). Dashed lines with triangles designate the surface fronts of the subducting plates. 


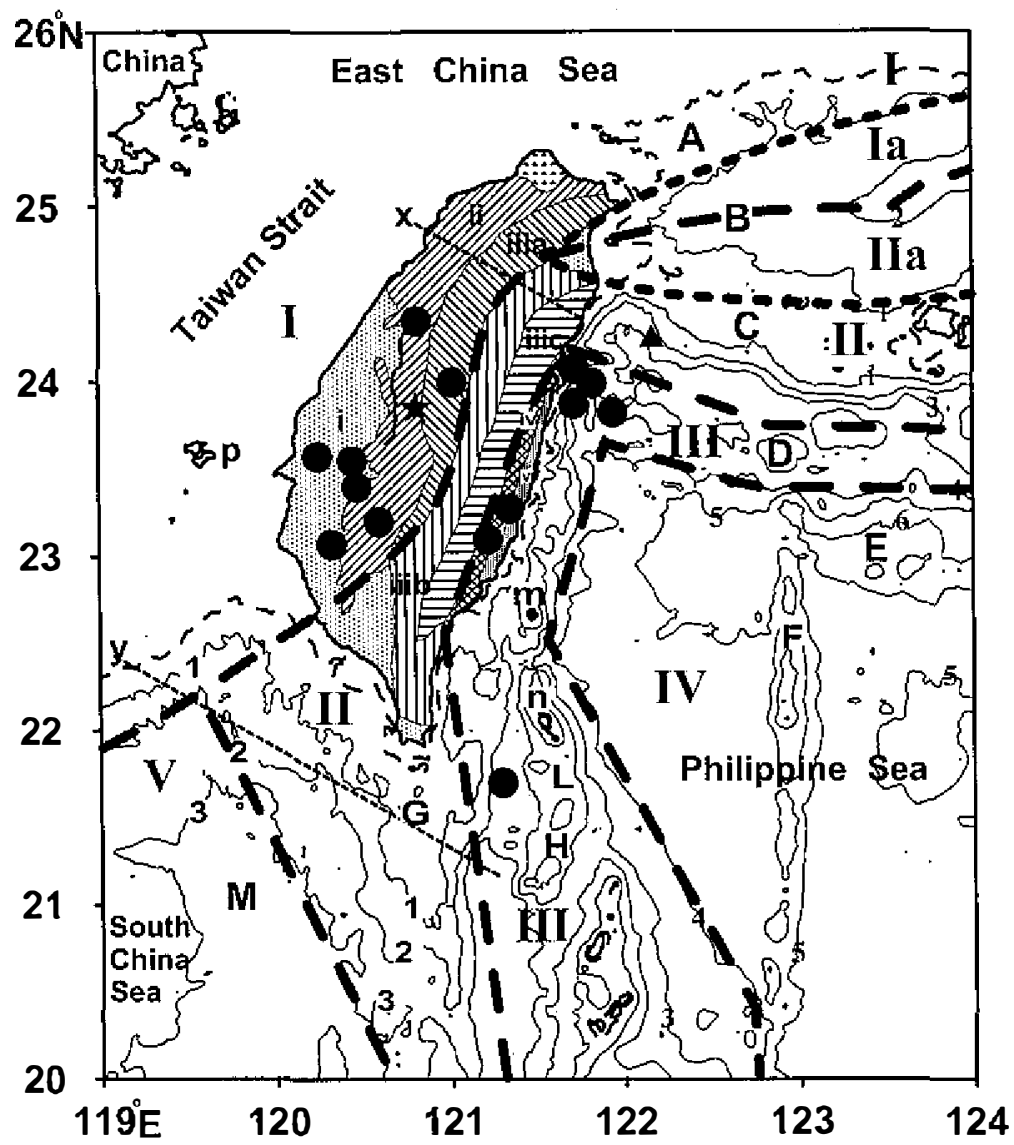

Fig. 2. Distribution of tectonic zones (separated by the dashed lines) and structural provinces background in the Taiwan region (Ho 1986, 1988). i: Western Coastal Plain; ii: Western Foothills; iiia: Hsueshan Range; iiib: Western flank of Central Range; iiic: Eastern flank of Central Range; iv: Longitudinal Valley; v: Coastal Range; A: Continental shelf-slope of East China Sea; B: Okinawa trough; C: Ryukyu arc; D: Forearc ridge; E: Ryukyu trench; F: Gagua ridge G: Hengchun ridge (forearc ridge); L: Luzon arc; M: Manila trench; m: Lutao (islet); n: Lanhsu (islet); p: Penghu islets; Bathymetric contour lines are in 1000 meters except for the dashed line which designates 200 meters. Superposed are epicenters of damaging earthquakes since 1900. The black dots are those listed in Cheng et al. (1999). The star is the Chi-Chi earthquake occurred on September 21, 1999 in central Taiwan. The solid curve on the western boundary of the Western Hills represents surface rupture caused by the Chi-Chi earthquake. The solid triangle is the March 31,2002 offshore earthquake. Lines $x$ and $y$ mark the region of uplifting due to compressive stress (see text for explanation). 
Okinawa trough, which extends from Japan to Taiwan. In the south, the South China Sea lithosphere (the oceanic part of the Eurasian plate) subducts beneath the Philippine Sea plate to form the Manila subduction system, including the Luzon arc and the Manila trench. Between these two subduction systems situates the Taiwan island as the transition zone with vigorous mountain building (Figs. 1, 2 and 3). The 1999 Chi-Chi Earthquake in central Taiwan (Fig. 2; e.g., Ma et al. 1999; Wang et al. 2000; Shin et al. 2000.), which caused extensive ruptures and the morphological change, is a vivid example of mountain building in this transition zone.

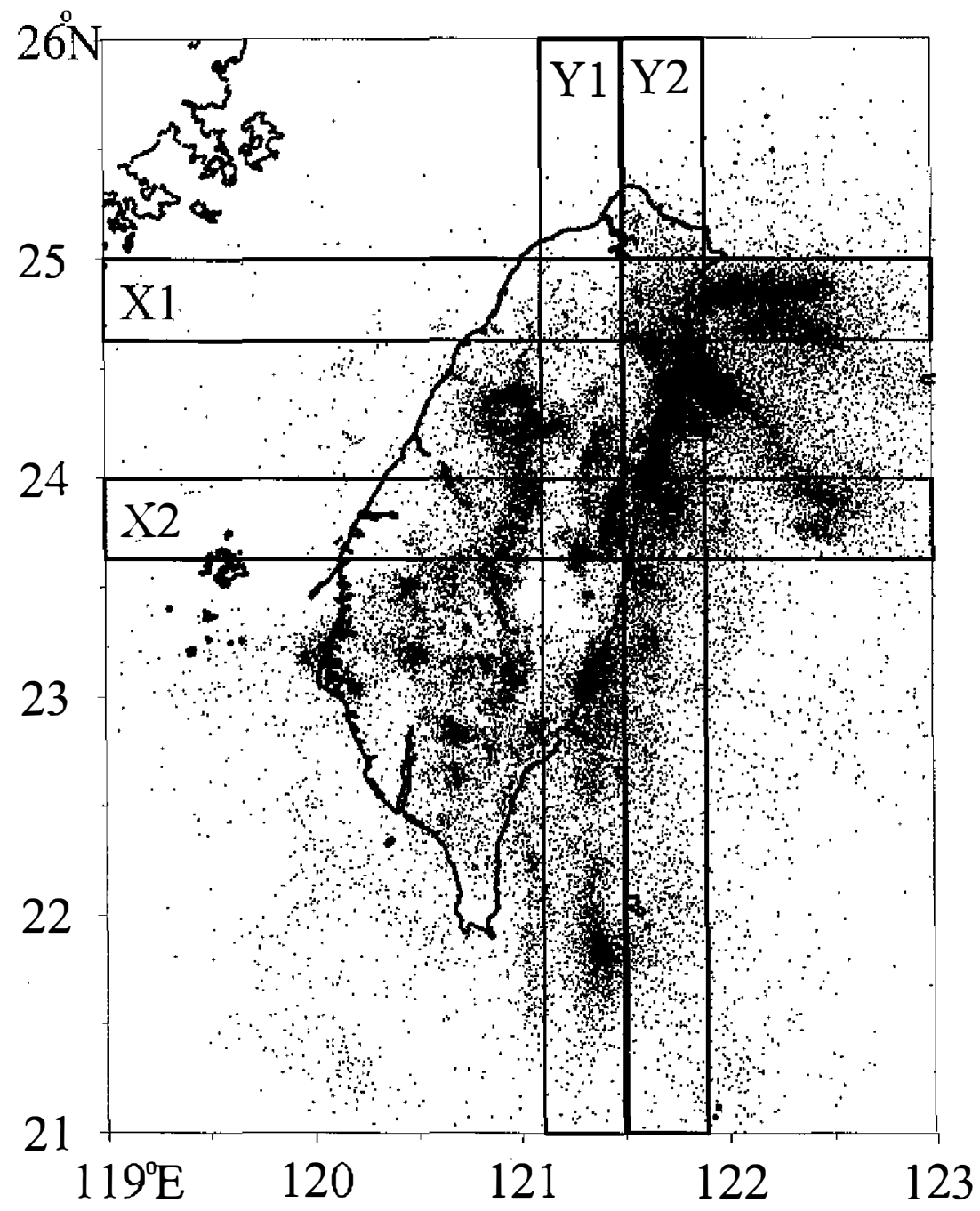

Fig. 3. Distribution of epicenters of earthquakes from 1991 to 2000, recorded and determined by the Seismological Observation Center, Central Weather Bureau of Taiwan. The superposed strips show earthquakes for plotting hypocentral profiles shown in Fig. 5. 
The mountain building originated from the oblique convergence of the western boundary of the Philippine Sea plate to the Eurasian continental plate margin bordering the northwest side of the South China Sea lithosphere. The oblique convergence shifted the mountain building site toward the southwest along with the migration of intersection point of the continental plate margin and the westem boundary of the Philippine Sea plate. Meanwhile, the generally westward extending Okinawa trough (e.g., Wang et al. 2000a; Wang et al. 2001; Teng 1996) causes subsidence of the northeastern Taiwan area. This makes the Taiwan island propagate southwestward through time as a transient solitary wave along the continental plate margin. This paper, describes the observed morphological, magnetic and seismological evidence suggesting the occurrence of this phenomenon.

\section{TECTONIC SETTING AND THE SQUEEZED TECTONIC ZONES IN TAIWAN}

The Ryukyu and the Manila subduction systems (Figs. 1 and 2) are perpendicular in orientation with different polarity of subduction. Both of them are attributed to the same northwestward movement of the Philippine Sea plate. However, they have different characteristics in nature. The former has been produced by active subduction of the Philippine Sea plate along the Ryukyu trench, and extends westward at its western end along with the westward-moving western boundary of the Philippine Sea plate beneath Taiwan, which trends north-south along about $121.5^{\circ} \mathrm{E}$ meridian line, with a speed of about $6 \mathrm{~cm} / \mathrm{y}$ (Wang et al. 2000a; 2001). The Manila subduction system has been produced by passive eastward subduction of the South China Sea lithosphere beneath the northwestward-moving Philippine Sea plate. Therefore, the Luzon arc is riding on the Philippine Sea plate and moves with it. The Manila trench, where the South China Sea lithosphere has been pushed beneath the riding Philippine Sea plate, is retreating westward as the western boundary of the Philippine Sea plate moves to the west. In other words, the subduction system is migrating westward to consume the South China Sea lithosphere.

Taiwan is the transition zone where the Ryukyu and Manila subduction systems change polarity of subduction (Fig. 1). Figure 2 shows the structural provinces of the Taiwan island (Ho 1986; 1988) and in the surrounding offshore areas. It also shows the epicenters of disastrous earthquakes that occurred since the beginning of the twentieth century. We divide the Taiwan region into five tectonic zones (separated by thick dashed lines in Fig. 2) according to its geology, geodesy (Chang et al. 2002), magnetism (Section 4 of this paper) and morphology. Zone $I$ is the Eurasian continental plate margin, including the Hsueshan Range and the Westerm Coastal Plain of Taiwan. Zone II covers the accretionary prism of the Manila subduction system, its northern extension and its basement, including the Central Range of Taiwan and the Ryukyu arc. The dividing line of Zone I and II passes through the center of the Okinawa trough. Zone III covers the northern Luzon arc and its remnants, including the Coastal Range and Longitudinal Valley of eastern Taiwan and the Yaeyama ridge (a forearc ridge of the Ryukyu subduction system; Fig. 2). The boundary between zones II and III passes through the forearc basins of the Manila and Ryukyu subduction systems. The deformation pattern based on satellite data in Taiwan (Chang et al. 2002) shows extensional deformation in Zone II and compressive deformation in Zones I and III in central and southern Taiwan. Zone IV is the 
northwestem comer of the Philippine Sea plate. Zone V is the northeastem comer of the South China Sea lithosphere. It is very interesting to see that all damaging earthquakes occurred in Zones I and III, except for the one which occurred on the northem boundary of the forearc basin of the Ryukyu subduction system. It is also interesting to observe that the tectonic zones are squeezed tightly along the length of Taiwan in central and southern Taiwan areas (between lines $\mathrm{x}$ and $\mathrm{y}$ in Fig. 2, where damaging earthquakes occurred; line $\mathrm{x}$ is the boundary between tensional and compressive stresses derived from earthquake mechanisms by Wang et al. 2000a; line $y$ lies in the offshore areas south of the southern tip of the Taiwan island and is in the direction of compressive stress as derived from earthquake focal mechanisms, which is perpendicular to the length of Taiwan). The rend of different tectonic zones changes to NE-SW in northern Taiwan, and further to E-W near the northeastern coastline. They then spread out, in general, to be the Ryukyu subduction system. This indicates that the central and southern Taiwan areas are in compressive stress while the northern Taiwan and the northeastern offshore areas are in tensional stress. Almost all damaging earthquakes occurred in the compressive area of Taiwan. These facts coincide with the tectonic setting that the transition zone (the Taiwan island) between two subduction systems with different polarity is the area of convergence of the western boundary of the Philippine Sea plate to the Eurasian continental plate margin.

\section{LITHOSPHERIC CONVERGENCE MODEL}

From Fig. 2, it is obvious that tectonic zones near the plate boundary are squeezed tightly and lie along the length of the island. These squeezed tectonic zones resulted from the convergence between the Eurasian and Philippine Sea plates in the ransition zone between the Ryukyu and Manila subduction systems. There are two principal models for orogeny mechanism in Taiwan: the arc-continent collision (e.g., Barrier and Angelier 1983; Teng 1990; Chang et al. 2000; Huang et al. 1997, 2000; Lundberg et al. 1997) and the arc-arc collision (Hsu and Sibuet 1995).

In the arc-continent collision model, the Luzon arc, riding on the Philippine Sea plate and moves northwestward along with it, collided with the Chinese continental shelf edge about 4ma (e.g., Chi et al. 1981; Teng 1990), and uplifted part of the continental edge to form the Taiwan island. In the arc-arc collision model, Hsu and Sibuet (1995) considered the orogensis in Taiwan resulted from the collision of the Luzon arc against the Ryukyu arc, and the Central Range of Taiwan is a portion of the latter. These models were proposed to interpret the surface geology in Taiwan, which indicates the uplifted and eroded surface of squeezed tectonic zones near the plate boundary (Fig. 2). In order to have a better understanding of this lithospheric convergence and the squeezing process of the tectonic zones, we establish a model of lithospheric convergence across central Taiwan, based on the distribution characteristics of earthquake hypocenters.

From the attitude of the Wadati-Benioff Zone, Wang et al. (2000b, 2001) observed that the western part of the lithosphere of the northward-subducting Philippine Sea plate underthrusts beneath the Taiwan island and that it has a western boundary running, in general, along the meridian line of $121.5^{\circ} \mathrm{E}$ (Fig. 4). These properties of the lithosphere are demonstrated in 


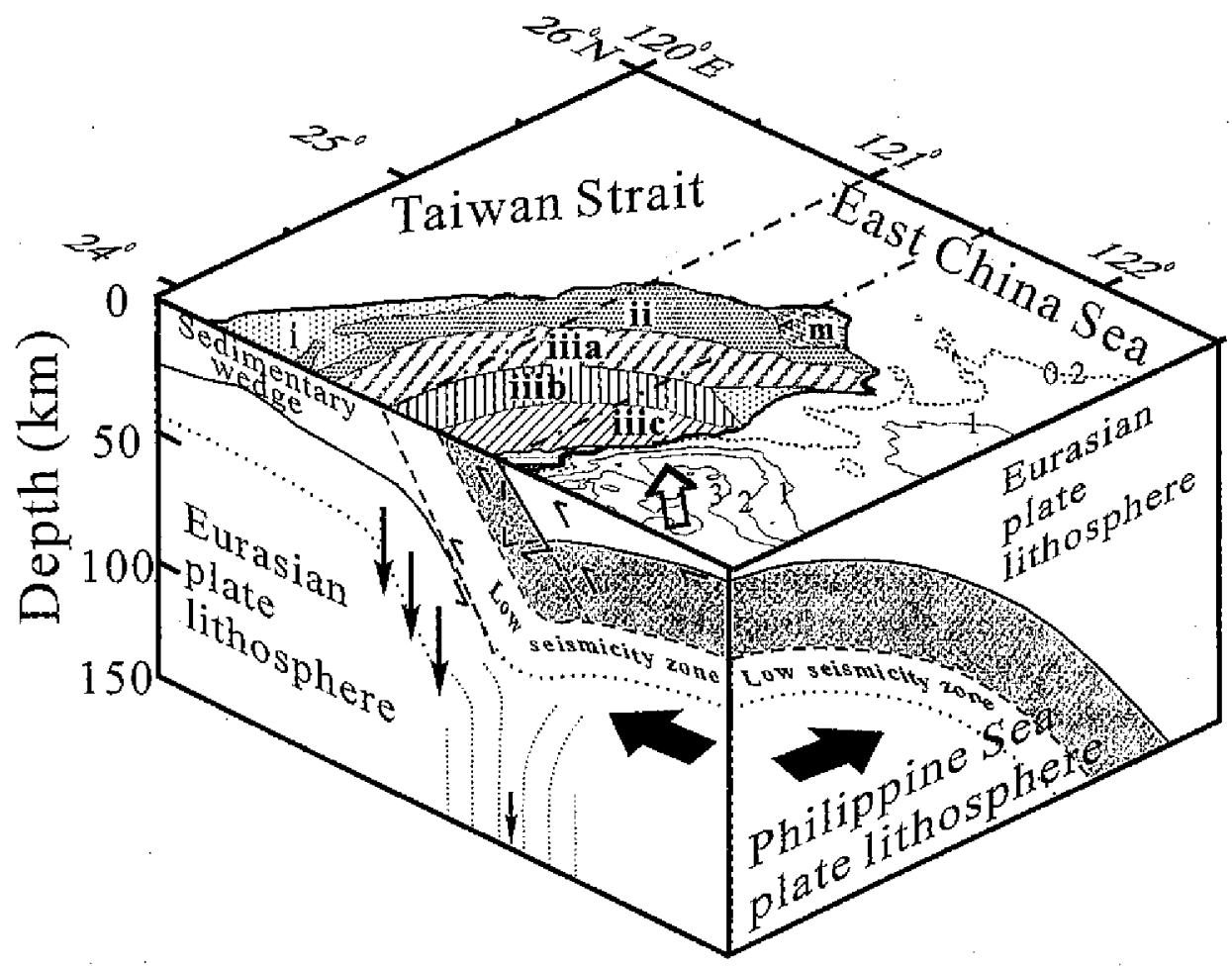

Fig. 4. Diagram illustrating model of lithospheric convergence across the central part of the Taiwan island. The two dashed and dotted lines along the meridians of $121.5^{\circ} \mathrm{E}$ and $121^{\circ} \mathrm{E}$ designate, respectively, the surface project lines of the western boundaries of the westward-underthrusting Philippine Sea plate lithosphere and the sliver of the seismic and low seismicity layers up-warping above the eastward-dipping South China Sea lithosphere (Eurasian oceanic plate). The model was modified from Wang et al. (2001), it was constructed according to the hypocentral profile shown in Fig. 5(X2). See text for further description.

Fig. 5. The western boundary of the Philippine Sea plate intersects the eastern Taiwan coastline at about $23.5^{\circ} \mathrm{N}$, where Shyu et al. (1996) separated the direct collision and the indirect collision of the Luzon arc against the Central Range (the Ryukyu arc) based on a geomagnetic study in the southeastern offshore area of Taiwan.

Yu et al. (1997) calculated the velocity of the Lanhsu islet, which is on the Luzon arc (Fig. 2), southeast of Taiwan, about $8 \mathrm{~cm} / \mathrm{y}$ in the direction of $\mathrm{N} 50^{\circ} \mathrm{W}$ based on the GPS observation data. We can easily obtain from it the western and northern components of the velocity of the Philippine Sea plate in the Taiwan region, and they are about $6 \mathrm{~cm} / \mathrm{y}$ and $5 \mathrm{~cm} / \mathrm{y}$, respectively. This indicates that the western boundary of the Philippine Sea plate is migrating westward at a slightly higher speed, while the plate is subducting northward at a lower speed.

On September 21, 1999, the most powerful earthquake (with Richter magnitude 7.3) in 
Taiwan of the last century, the Chi-Chi earthquake, occurred in central Taiwan (Fig. 2). It caused extensive surface ruptures, totaling about $100 \mathrm{~km}$ in length, mainly at the foot of the Western Foothills (Fig. 2). It also caused an extensive crustal deformation in central Taiwan (e.g., Rau et al. 1999; Liu et al. 1999; Chung and Shin 1999). It is clear that the intersection of the boundaries of the Eurasian continental plate and the Philippine Sea plate lays in central Taiwan (Fig. 2). A tomographic study of the P-wave velocity structure in the central Taiwan area (personal communication with Dr. Win-Bin Cheng at Jin-Wen Institute of Technology at Taipei) confirmed that the Peikang basement high southwest of Taiwan was blocking the westward movement of the Taiwan island (e.g. Wang et al. 2000b). Figure 6 shows the location of the Peikang basement high in the background of the topography of Taiwan. It is interesting to see that the Peikang basement high is the center of several concentric topographic rings in Taiwan.

The profile of the model of lithospheric convergence between the Eurasian and Philippine Sea plates shown in Fig. 4 is constructed mainly according to the E-W trending hypocentral profile along $24^{\circ} \mathrm{N}$ (Fig. 5, Profile X2). In Fig. 4, the shaded areas in the N-S and E-W crosssections show the upper lithospheric layer of the Eurasian and Philippine Sea plates, which
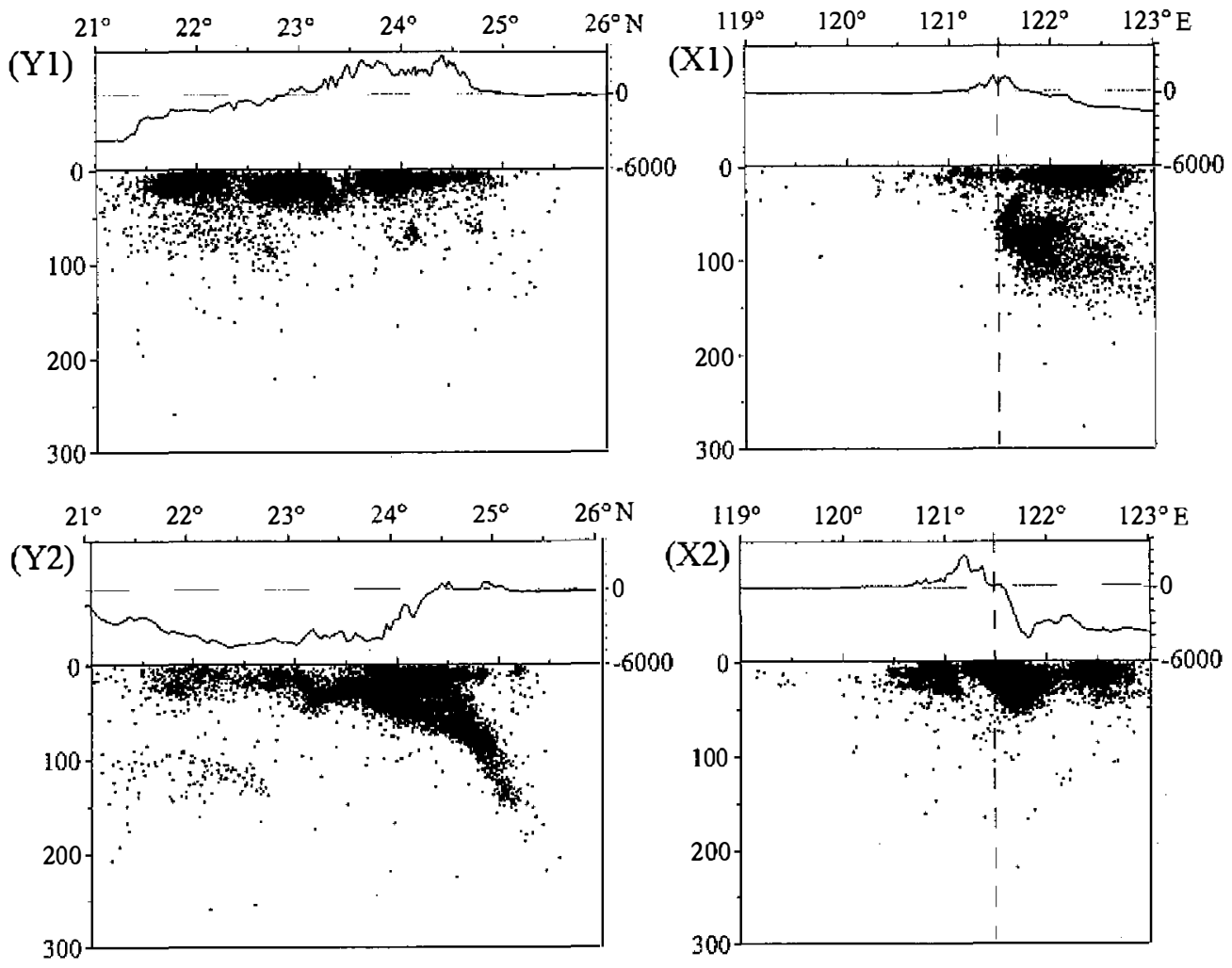

Fig. 5. Hypocentral profiles for zones shown in Fig. 3. They demonstrate the Benioff-Wadati Zone and its western boundary (dashed). See detaiks in Wang et al. (2000b, 2001). 
mainly correspond to the seismic layer in Profile X2 of Fig. 5. The Philippine Sea plate subducts northward and underthrust westward at the same time. Below its seimic layer (the Benioff zone), there is a layer of low seismicity of about $20 \mathrm{~km}$ in thickness, which may be weaker, due to higher temperature, than its overlying seismic layer. The westernmost portion of these two layers pressed the Eurasian plate down and warped up along the eastward-dipping slope. The warping has happened beneath the Coastal Range and its eastern offshore area in eastern Taiwan, probably associated with the weakening of lithosphere due to magmatic activity that created the northern Luzon arc. The underthrusting and up-warping portions of these two layers have been moving westward, along with the Philippine Sea plate, to push up and squeeze the material above and before tectonic zones forming the Taiwan island.

According to Fig. 4, we separated at the base of the low-seismicity layer, the Philippine Sea plate into two parts. The upper part comprises the seismic and low-seismicity layers mentioned above, which are directly responsible for orogenesis in Taiwan. The lower part sinks together with the Eurasian plate (the South China Sea lithosphere) beneath the eastern Taiwan area, along the meridian line of about $121.5^{\circ} \mathrm{E}$. The Philippine Sea plate subducts northward to the east of the same meridian line, implying presence of relative shear motion between the Eurasian and Philippine Sea plates beneath Taiwan.

\section{PROPAGATION OF THE TAIWAN ISLAND AS A SOLITARY WAVE}

From the discussion above, it is clear from Fig. 2 and 4 that orogen in Taiwan have been built by squeezing and uplifting of tectonic zones on the plate boundary, including the continental shelf-slope of the Eurasian plate, the accretionary prism and the Luzon arc of the Manila subduction system. The squeezing and uplifting of tectionic zones have been caused by lithospheric convergence of the Philippine Sea plate to the Eurasian continental plate margin. However, the convergence is oblique and migrating southwestward. Thus the Taiwan island has been propagating as a solitary wave due to the migration of the convergence.

Figure 7 is the magnetic anomaly map in the Taiwan region. It shows a pair of two parallel prominent bands of magnetic anomaly, a high in the south and a low in the north, trending about $\mathrm{N} 60^{\circ} \mathrm{E}$ (Figs. 7 and 8 ) in the southwestern offshore area of Taiwan. These bands are the main magnetic characteristics of the Eurasian continental margin bordering the South China Sea on the northwestem side, indicating that there must be a buried volcanic ridge or a band of magmatic intrusions/extrusions almost along the boundary of these two bands of magnetic anomaly. These two bands clearly exist in the Western Coastal Plain and Hsueshan Range (Fig. 7), indicating that these two tectonic units are parts of the continental margin (Zone I in Fig. 2), whose eastern boundary can be clearly identified from the magnetic anomaly map (Fig. 7), the geology (Fig. 2), morphology (Fig. 6) and the surface strain pattern derived from satellite data (Chang et al. 2002).

The Peikang basement high (Fig. 6) and the Penghu islets in Taiwan Strait (Fig. 2) should belong to the volcanic ridge associated with the bands of high and low anomaly (Fig. 7). From Fig. 6, it is clear that the eastern portion of the volcanic ridge and the surrounding continental plate margin material was uplifted due to the stress from the Central Range (Figs. 2 and 6) and the seismic and low-seismicity layers of the Philippine Sea plate lithosphere (Fig. 4). The 
orogen built this way on the continental plate margin will become the southwestern extension of the Hsueshan Range (Figs. 2 and 6). Figure 7 also shows another band of high magnetic anomaly along the continental plate margin of East China Sea. This band relates to the opening of the Okinawa trough, because it is the northwestern border of the latter. This band of high magnetic anomaly may extend southwestward along with the Okinawa trough.

Wang et al. (2000b, 2001) indicated the western boundary of the lithosphere of the Philippine Sea plate is at the meridian line of $121.5^{\circ} \mathrm{E}$ (Figs. 4 and 8). The lithosphere underthrusts westward east of this meridian line (Fig. 4). The Philippine Sea plate moves at a speed of 8 $\mathrm{cm} / \mathrm{y}$ (i.e., $80 \mathrm{~km} / \mathrm{my}$ ) in the direction of $\mathrm{N} 50^{\circ} \mathrm{W}$ (Yu et al. 1997). As shown in Fig. 8, the intersection of the western boundary of the Philippine Sea plate and the Eurasian continental margin migrates southwestward along the band of high magnetic anomaly bordering the South China Sea lithosphere on the northwestern side, with a speed of about $7 \mathrm{~cm} / \mathrm{y}$ (i.e., $70 \mathrm{~km} / \mathrm{my}$; Fig. 8). Since the Taiwan island is built by uplifting of tectonic zones (Fig. 2) on the plate boundary near the intersection point, it is propagating as a solitary wave at the same speed and in the same direction with the intersection point. Figure 8 also shows the positions of Taiwan island for different geological times with one million years apart. One should notice that the area of the Taiwan island did not necessarily change substantially with time because it is propagating as a solitary wave (Fig. 9) along the continental plate margin.

The vertical displacement (Fig. 9a) of different parts of the Taiwan island is 90 degrees in phase behind the uplifting speed (Fig. 9b). As we demonstrated for the present Taiwan island (Figs. 8 and 9), the material, as the medium of the solitary wave, starts to gain uplifting speed south of the southern tip of Taiwan island (line y in Figs. 2 and 8). The speed increases northeastward along the length of Taiwan until it reaches the maximum at about $23.5^{\circ} \mathrm{N}$ near the center of the Peikang basement high (Fig. 6) on the Western Coastal Plain of Taiwan (Fig. 2). The speed then decreases until it become zero in northern Taiwan (line $x$ in Figs. 2 an 8), and then become negative further northeast. However, the vertical displacement (Fig. 9a) of the basement material reaches the maximum in northern Taiwan (line $\mathrm{x}$ ), where the uplifting speed (Fig. 9a) starts to become negative. It is therefore obvious that the central and southern Taiwan areas south of line $\mathrm{x}$ are uplifting, and the northern Taiwan area north of this line is subsiding.

\section{CONCLUSIONS}

1. The Taiwan island is situated in the transition zone between the Ryukyu and Manila subduction systems with different subduction polarity, and was formed by uplifting the squeezed tectonic zones on the boundary between the convenging Eurasian continental plate and the Philippine Sea plate. Three major tectonic zones are involved in mountain building in the Taiwan island. These zones are squeezed and uplifted, with their length perpendicular to the compressive stress caused by movement of the Philippine Sea plate.

2. The westward movement of the western boundary of the Philippine Sea plate makes the oblique convergence of this boundary to the Eurasian continental plate margin migrate southwestward, causing the Taiwan island to behave as a solitary wave which propagates southwestward along with the convergence. 


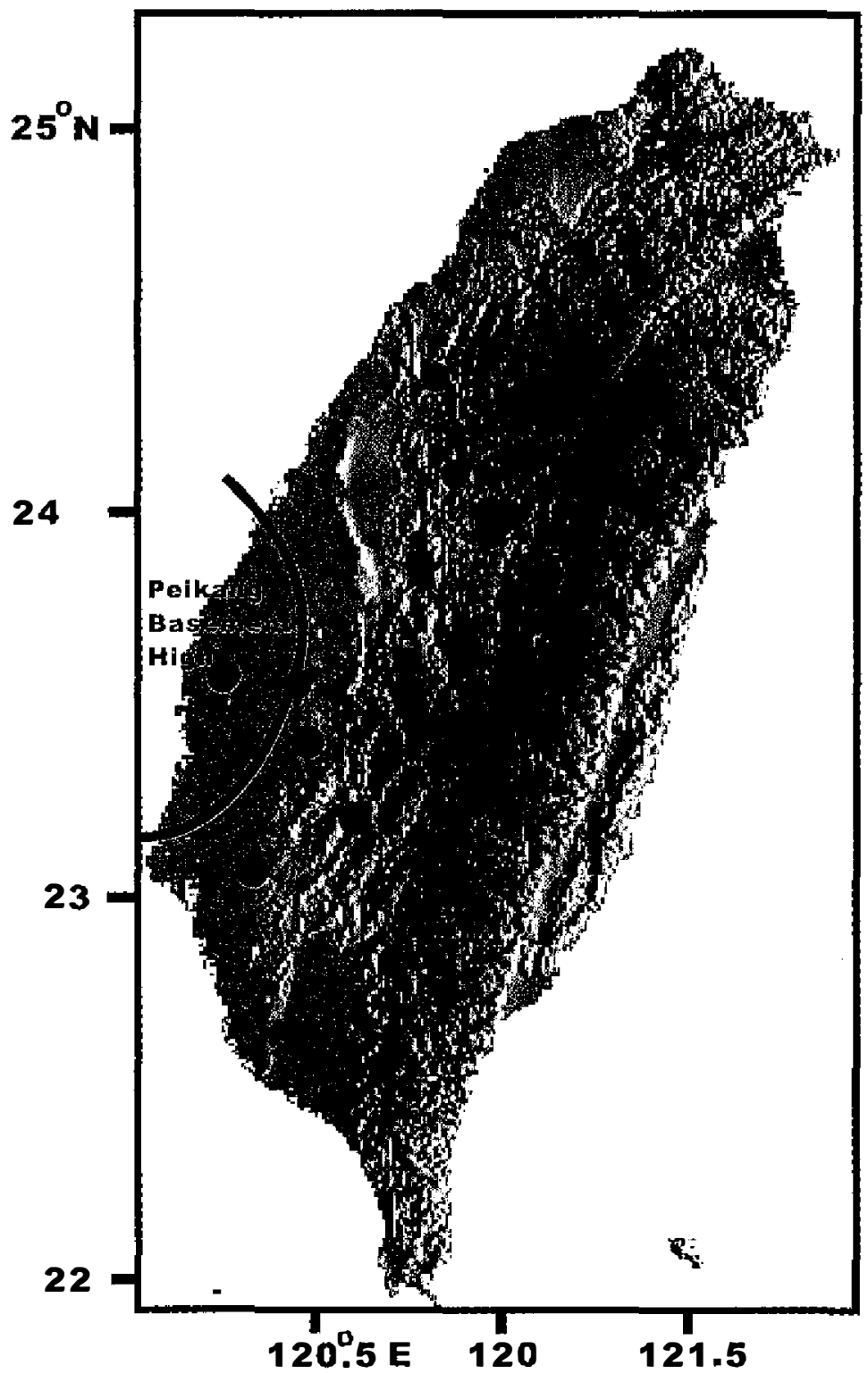

Fig. 6. Diagram indicating the location of the Peikang basement high as determined by Cheng et al. (2002) with the P-wave velocity residual at $10 \mathrm{~km}$ in depth derived by a seismic tomographic method. The background is the topography of Taiwan provided by Institute of Geophysics, National Central University (at Chungli, Taiwan) and the epicenter of damaging earthquakes in western Taiwan listed in Cheng et al. (1999). Notice that the Peikang basement high is the center of several topographic concentric rings in southwestern Taiwan. 


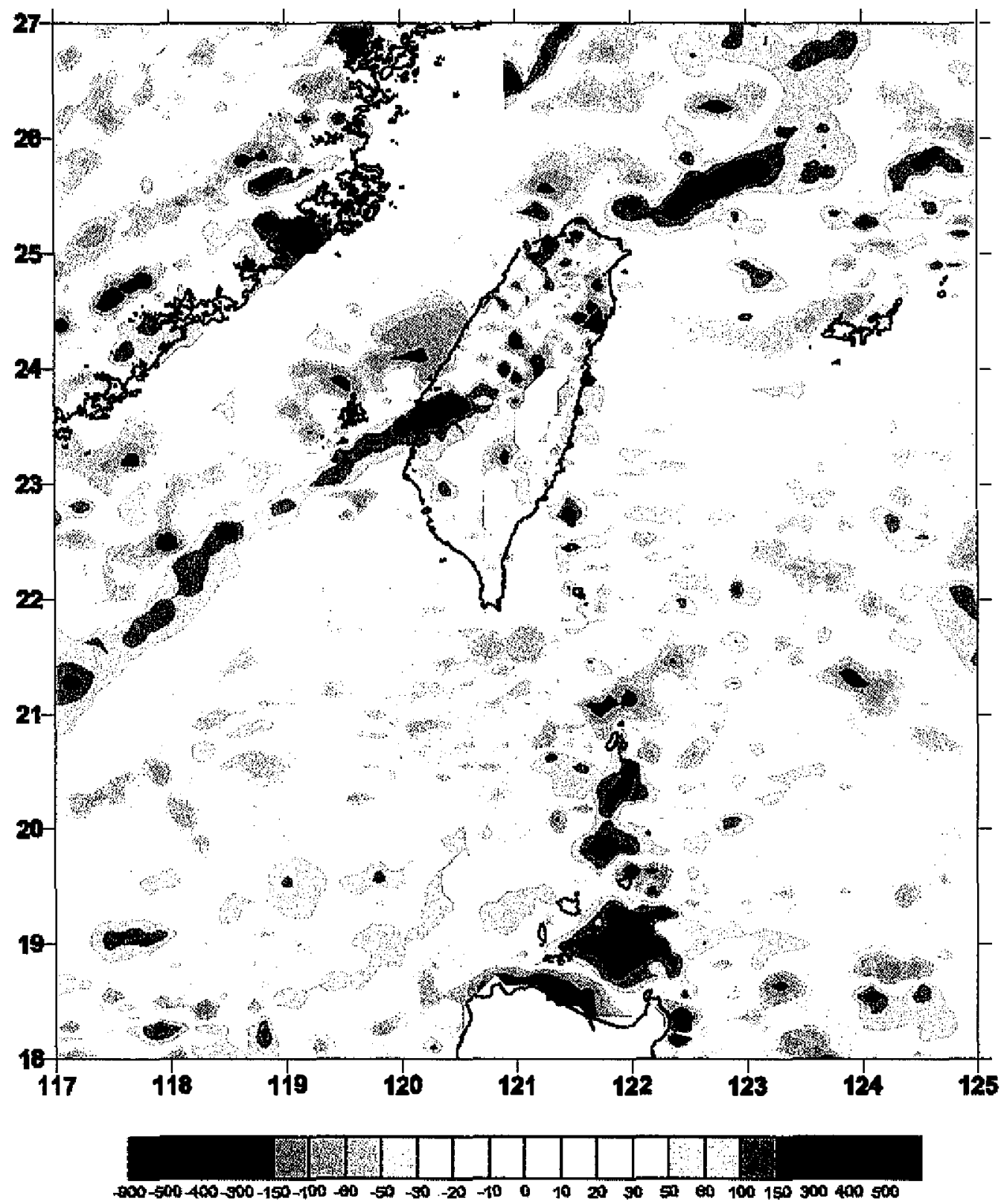

Fig. 7. Map of magnetic anomaly in the Ryukyu -Taiwan-Luzon region. The data are obtained from Hsu et al. (1998) except for those on Taiwan, which were obtained in recent surveys in the last two years.

Acknowledgements This study was supported by National Science Council of Taiwan. We are grateful to the Seismological Observation Center, Central Weather Bureau of Taiwan for providing us with the seismicity data used in the study. 


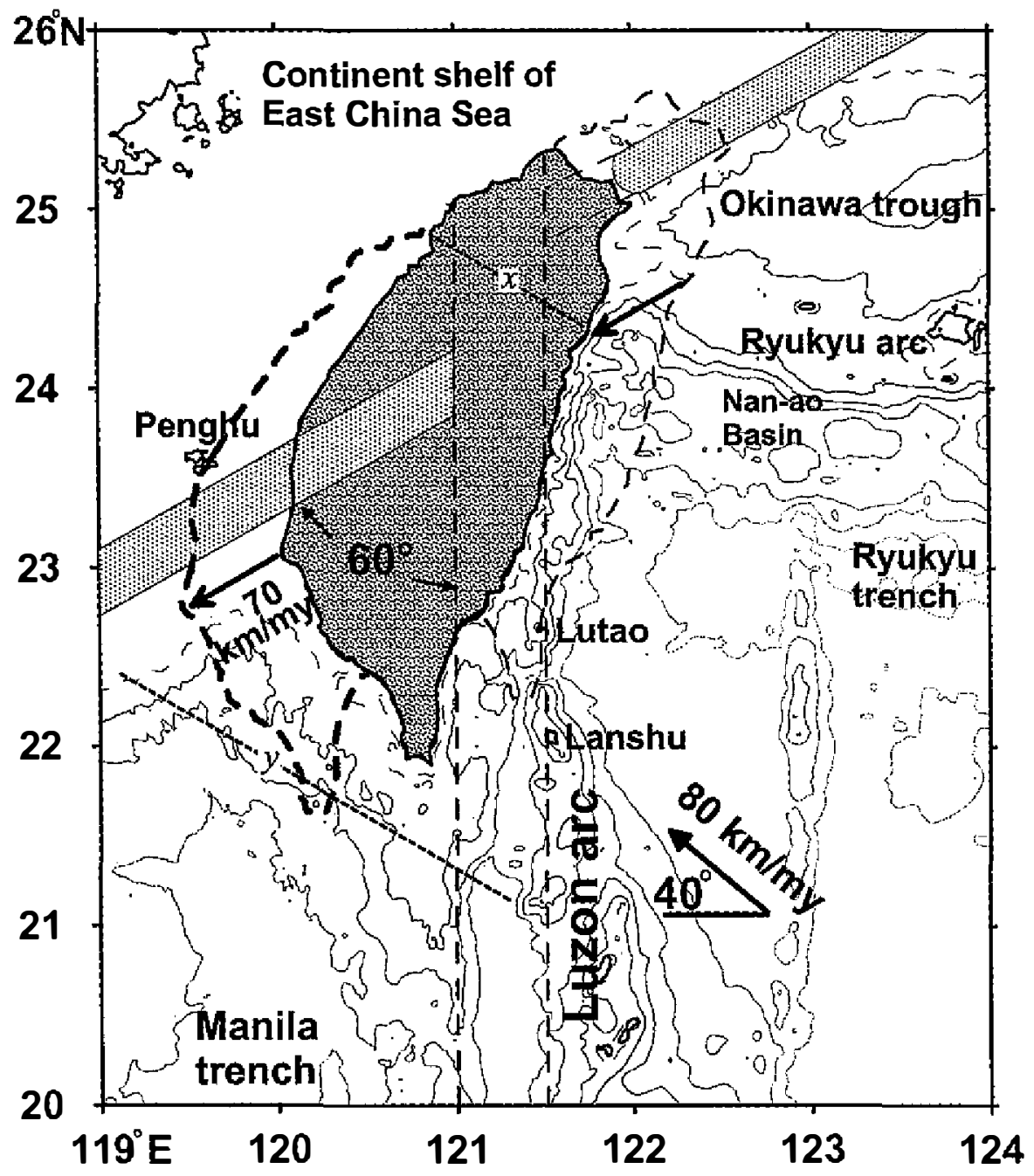

Fig. 8. Diagram showing the forming environment of the Taiwan island as a solitary wave along the Eurasian continent margin due to the convergence of the lithospheres of the Philippine Sea plate and the Eurasian continent plate. The two dashed lines along the meridian lines of 121 . $5^{\circ} \mathrm{E}$ and $121^{\circ} \mathrm{E}$. designate, the respectively, western boundaries of the westward under-thrusting Philippine Sea plate lithosphere and the sliver of seismic and low seismicity layers up-wrapping above the eastwarddipping South China Sea lithosphere (Fig. 4). Positions of the Taiwan island for different geological times with one million years apart are shown, with the present position shadowed. The shadowed straight zones show positions of bands of high magnetic anomaly southwest and northeast of Taiwan, separately. 

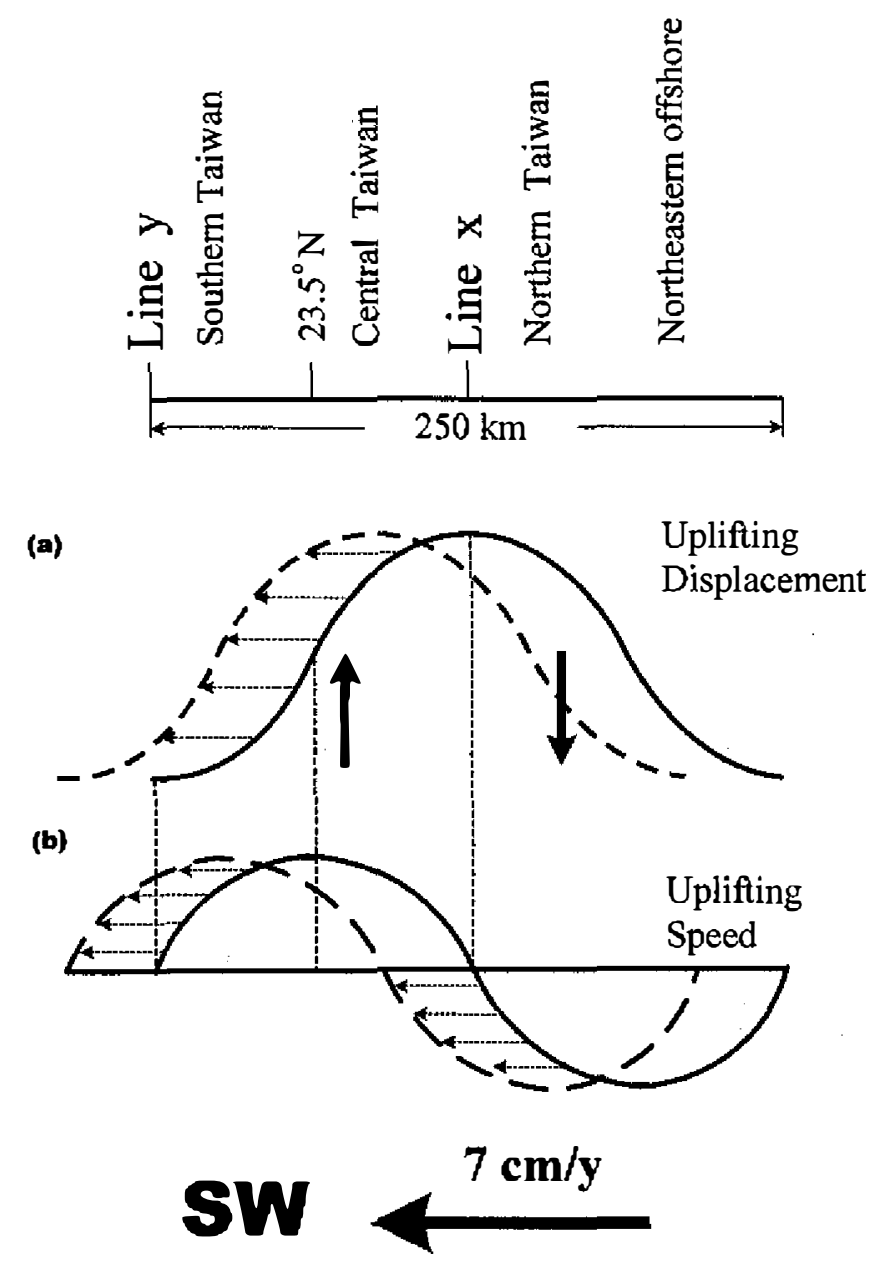

Fig. 9. The solitary wave demonstrating the displacement (a) and speed (b) of the uplifting of the Taiwan island. Shown above the solitary wave are positions with respect to the present Taiwan.

\section{REFERENCES}

Barrier, E., and J. -C. Sibuet, 1983: Active collision in eastern Taiwan: the Coastal Range. Mem. Geol. Soc. China, 7, 135-159.

Chang, C. P., J. Angelier, and C. Y. Huang, 2000: Origin and evolution of a melange: the active plate boundary and suture zone of the Longitudinal Valley, Taiwan. Tectonophysics, 325, 43-62.

Chang, C. P., J. Angelier, C. Y. Huang, and C. S. Liu, 2001: Structural evolution and significance of a melange in a collision belt: the Lichi Melange and the Taiwan arc-continent collision. Geol. Mag., 138, 633-651.

Chang, C. P., T. Y. Chang, J. Angelier, H. Kao, J. C. Lee, and S. B. Yu, 2002: Strain and stress 
field in Taiwan oblique convergent system: constraints from GPS observations and tectonic data, Earth Planet. Sci. Lett. (Submitted).

Cheng, W. B., and C. Wang, 2001: Seismogenic zones in the convergent margin, eastern Taiwan and its implications in the Luzon forearc deformation. TAO, Suppl. May, 269286.

Cheng, W. B., Wang, C. T. Shyu, and T. C. Shin, 1998: A Three-dimensional Vp model of the southeastem Taiwan area and its tectonic implications. TAO, 9, 425-452.

Cheng, S. N., Y. T. Yeh, M. T. Hsu, and T. C. Shin, 1999: Photo album of the disastrous earthquakes in Taiwan, Central Weather Bureau, Ministry of Communications of Taiwan (in Chinese).

Chi, W. R., J. Namson, and J. Suppe, 1981: Stratigraphic records of plate interactions in the Coastal Range of eastern Taiwan. Mem. Geol. Soc. China, 4, 15-194.

Chung, J. K., and T. C. Shin, 1999: Implications of the rupture process from the displacement distribution of strong ground motions recorded during the 21 September, 1999 Chi-çi, Taiwan earthquake. TAO, 10, 777-786.

Ho, C. S., 1986: A synthesis of the geological evolution of Taiwan. Tectonophysics, 125, 116.

Ho, C. S., 1988: An introduction to the geology of Taiwan, 2nd ed., Central Geological Survey, The Ministry of Economic Affairs, Taipei, 192pp (in Chinese).

Hsu, S. K., C. S. Liu, C. T. Shyu, S. Y. Liu, J. -C. Sibuet, S. Lallemand, C. Wang, and D. Reed, 1998: New gravity and magnetic anomaly maps in the Taiwan-Luzon region and their preliminary interpretation. TAO, 9, 509-532.

Hsu, S. K., and J. -C. Sibuet, 1995: Is Taiwan the result of arc-continent or arc-arc collision? Earth Planet. Sci. Lett., 136, 315-324.

Huang, C. Y., W.Y. Wu, C. P. Chang, S. Tsa, P. B. Yuan, C. W. Lin, and K. Y. Xia, 1997. Tectonic evolution of accretionary prism in the arc-continent collision terrane of Taiwan. Tectonophysics, 281, 31-51.

Huang, C. Y., P. B. Yuan, C. W. Lin, T. K. Wang, and C. P. Chang, 2000: Geodynamic processes of Taiwan arc-continent collision and comparison with analogs in Timor, Papua New Guinea, Urals and Corsica. Tectonophysics, 325, 1-21.

Lee, T. Y., and L. A. Lawver, 1994: Cenozoic plate reconstruction of the South China Sea region. Tectonophysics, 235, 149-180.

Liu, C. C., I. H. Su, C. H. Hou, C. F. Lee, and T. C. Lai, 1999: Co-seismic and post-seismic deformation caused by the 1999 September 21 Chi-Chi earthquake in central Taiwan. National Science Newsletter of the National Science Council of Taiwan, 156-161 (in Chinese).

Lundberg, N., D. L. Deed, C. S. Liu, and J. J. Lieske, 1997: Forearc-basin closure and arc accretion in the submarine suture zone south of Taiwan. Tectonophysics, 274, 5-23.

Ma, K. F., C. T. Lee, Y. B. Tsai, T. C. Shin, and J. Mori, 1999: The Chi-Chi, Taiwan, earthquake: large surface displacements on an island thrust. EOS, 80, 605-611.

Rau, R. J., J. Y. Yu, T. T. Yu, M. Yang, and C. L. Tseng, 1999: Co-seismic displacements of the 1999 Chi-Chi, Taiwan earthquake sequence. AGU 1999 Fall Meeting Program, p. 15. 
Shin, T. C., K. W. Kao, W. H. K. Lee, T. L. Teng, and Y. B. Tsai, 2000: A preliminary report on the Chi-Chi (Taiwan) earthquake. Seism. Res. Lett, 71, 24-30.

Shyu, C. T., M. C. Chih, S. K. Hsu, C. Wang, and B. Karp, 1996: Northern Luzon arc: location and tectonic features from magnetic data of eastern Taiwan. TAO, 7, 535-548.

Teng, L. S., 1990: Geotectonic evolution of the late Cenozoic arc-continent collision. Tectonophysics, 183, 57-76.

Teng, L. S., 1996: Extensional collapse of the northem Taiwan mountain belt. Geology, 24, 947-952.

Wang, C., S. W. Chuang, M. L. Li, and W. B. Cheng, 2001: Lithospheric structure of Philippine Sea plate near the western end of Ryukyu subduction zone and some of its tectonic effects. TAO, Suppl. May, 287-304.

Wang, C., T. H. Huang, I. C. Yen, S. L. Wang, and W. B. Cheng, 2000b: Tectonic environment of the 1999 Chi-Chi earthquake in central Taiwan and its aftershock sequences. TAO, 11, 661-678.

Wang, C., M. L. Yang, C. P. Chou, Y. C. Chang, and C. S. Lee, 2000a: Westward extensionof the Okinawa trough at its western end in the northern Taiwan area: Bathymetric and seismological evidence. TAO, 11, 450-480.

Wang, C. Y., C. H. Chang, and H. Y. Yen, 2000: An interpretation of the 1999 Chi-Chi earthquake in Taiwan based on the thin-skinned thrust model. TAO, 11, 609-630.

Yu, S. B., H. Y. Chen, and L. C. Kuo, 1997: Velocity field of GPS stations in the Taiwan area. Tectonophyscis, 274, 41-59. 